\title{
The problem of unemployment in the Republic of Serbia with specific regard to informal employment
}

\begin{abstract}
Unemployment in Serbia is very high. Women are affected by unemployment more severely than men, despite their higher level of educational attainment, and the unemployment rate for women has been significantly higher than that for men. Young people (15-24 years old) also have an exceptionally low employment-to-population ratio (18.7\% in 2005 and $15 \%$ in 2010). Unfavourable demographic trends have also contributed to the worsening of the main labour market indicators in Serbia. After the onset of the crisis, employment has fallen more steeply than has GDP. This means that Serbia had, in the previous period, very high employment elasticity. The National Employment Strategy for the Period 2011-2020 aims to support the future development of Serbia with employment creation and the reduction of relative poverty at its core. In pursuing its objectives, the Employment Strategy will also focus on supporting pro-investment approaches and export-oriented industries, as set out in the post-crisis economic development and growth model.
\end{abstract}

Keywords: employment rate, unemployment rate, informal employment rate, education, active employment policy

\section{Introduction}

The general characteristics of the labour market in the Republic of Serbia are: high rates of unemployment, especially of youth unemployment; a mismatch between supply and demand in terms of the labour force; a high proportion of long-term unemployment; a disadvantageous age and skill structure among unemployed people; significant differences between regional labour markets; a low mobility of the workforce; a large proportion of job seekers with low employability; and a significant informal employment sector.

Implementation of employment policy in the Republic of Serbia is within the jurisdiction of the Ministry of Economy and Regional Development.

The Law on Employment and Unemployment Insurance ${ }^{1}$ specifies as employment agents the National Employment Service and employment agencies, defining their position and jurisdiction.

The National Employment Service (NES) undertakes employment activities as well as those concerning unemployment insurance and the exercise of other entitlements. It also keeps records in the area of employment. For more effective detailed operation, a provincial employment service and branch offices in the larger local self-governments

1 Official Gazette of the Republic of Serbia 36/09. 
have been established within the purview of the NES. NES branch offices cover the whole territory of the Republic of Serbia. With the approval of the Ministry of the Economy and Regional Development, NES can engage an employment agency for the implementation of certain programmes and measures under the National Action Plan for Employment for 2011, as well as for the development and execution of individual employment plans, notably for specific categories of the unemployed (for example, people with disabilities). Currently, there are 52 registered employment agencies operational. NES has signed with a certain number of them a Code of Co-operation which, among other things, regulates mutual relations.

\section{Unemployment and employment rates}

The most recent Labour Force Survey was conducted in April 2011, on a sample of approximately 8000 households in Belgrade, central Serbia and AP Vojvodina. Data were collected on the demographic characteristics of all respondents, including those on the working activities of people aged 15 and over. A total of 13029 persons were interviewed and data on the working activities of a sample of 20277 persons were obtained.

The main aim in conducting the Labour Force Survey is to collect data on the working characteristics of the population and to provide an estimate of the total labour force in the country according to international recommendations and definitions. Its aim is to provide data on the three basic, mutually exclusive contingents of the population aged 15 and over: i.e. the employed, unemployed and inactive population. The whole population is classified in one of these groups on the basis of information provided from the questionnaire regarding the activity in the observed week of those who are interviewed in the Survey.

The labour force (the active population) includes all those who are in work (for at least one hour in a week) or those who are actively seeking work, with the aim of providing the basic means for living.

The unemployment rate $^{2}$ in April 2011 in the Republic of Serbia amounted to $22.2 \%$; with $22.0 \%$ of men and $22.5 \%$ of women being out of work. The unemployment rate in the city of Belgrade amounted to $18.9 \%$ and in AP Vojvodina to $22.9 \%$. In the region of Sumadija and western Serbia, the unemployment rate was $22.0 \%$, while in the region of southern and eastern Serbia, it amounted to $24.8 \%$.

The employment rate ${ }^{3}$ in April 2011 amounted to $36.2 \%$, climbing to $43.2 \%$ among the male population and dropping to just $29.8 \%$ among women. The largest employment rate was recorded in Sumadija and western Serbia, amounting to $37.8 \%$, followed by Belgrade (36.5\%). In southern and eastern Serbia, it amounted to $35.3 \%$ whereas the lowest rate was recorded in AP Vojvodina, of just $35.0 \%$.

2 The unemployment rate presents the share of the unemployed in total active population (employed and unemployed).

3 The employment rate presents the percentage of the employed in the total population aged 15 and over. 
The problem of unemployment in the Republic of Serbia with specific regard to informal employment

Table 1 - Unemployment and employment rates

\begin{tabular}{|l|c|c|c|c|}
\hline & October 2009 & April 2010 & October 2010 & April 2011 \\
\hline Unemployment rate & 16.6 & 19.2 & 19.2 & 22.2 \\
\hline Employment rate & 40.8 & 38.1 & 37.7 & 36.2 \\
\hline Informal employment rate & 20.6 & 19.8 & 19.6 & 19.9 \\
\hline
\end{tabular}

Source: Statistical Office of the Republic of Serbia Labour Force Survey

The unemployment rate in April 2011 increased by three percentage points compared to April 2010, while the employment rate decreased by 1.9 percentage points. The unemployment rate in April 2011 was also three percentage points higher on the October 2010 figure, whereas the employment rate was lower by 1.5 points.

In contrast, the informal employment rate ${ }^{4}$ in April 2011 was higher by 0.3 percentage points compared to the October 2010 total and by 0.1 points compared to the April 2010 figure.

Table 2 - Employment and unemployment rates

\begin{tabular}{|l|c|c|c|c|c|}
\hline Year & $\begin{array}{c}\mathbf{2 0 0 8} \\
\text { April }\end{array}$ & $\begin{array}{c}\mathbf{2 0 0 8} \\
\text { October }\end{array}$ & $\begin{array}{c}\mathbf{2 0 0 9} \\
\text { April }\end{array}$ & $\begin{array}{c}\mathbf{2 0 0 9} \\
\text { October }\end{array}$ & $\begin{array}{c}\mathbf{2 0 1 0} \\
\text { April }\end{array}$ \\
\hline $\begin{array}{l}\text { General employment rate } \\
\text { (ages 15-64) }\end{array}$ & $54.0 \%$ & $53.30 \%$ & $50.80 \%$ & $50.00 \%$ & $47.2 \%$ \\
\hline $\begin{array}{l}\text { General unemployment rate } \\
\text { (ages 15-64) }\end{array}$ & $14.0 \%$ & $14.70 \%$ & $16.40 \%$ & $17.40 \%$ & $20.1 \%$ \\
\hline
\end{tabular}

Table 3 - Key labour market indicators, by sex

\begin{tabular}{|l|c|c|c|c|c|c|c|c|c|c|}
\hline \multirow{2}{*}{$\begin{array}{l}\text { LFS for working age } \\
\text { population } \\
\text { 15-64 }\end{array}$} & \multicolumn{2}{|c|}{$\begin{array}{c}\mathbf{2 0 0 8} \\
\text { April }\end{array}$} & \multicolumn{2}{c|}{$\begin{array}{c}\text { 2008 } \\
\text { October }\end{array}$} & \multicolumn{2}{c|}{$\begin{array}{c}\text { 2009 } \\
\text { April }\end{array}$} & \multicolumn{2}{c|}{$\begin{array}{c}\text { 2009 } \\
\text { October }\end{array}$} & \multicolumn{2}{c|}{$\begin{array}{c}\text { 2010 } \\
\text { April }\end{array}$} \\
\cline { 2 - 13 } & M & F & M & F & M & F & M & F & M & F \\
\hline Employment rate (\%) & 62.3 & 46.0 & 62.2 & 44.7 & 58.7 & 43.3 & 57.4 & 42.7 & 54.3 & 40.3 \\
\hline Unemployment rate (\%) & 12.4 & 16.1 & 12.7 & 17.3 & 15.0 & 18.1 & 16.1 & 19.1 & 19.4 & 20.9 \\
\hline Activity rate (\%) & 71.1 & 54.8 & 71.3 & 54.1 & 69.0 & 52.8 & 68.4 & 52.8 & 67.4 & 50.9 \\
\hline Inactivity rate (\%) & 28.9 & 45.2 & 28.7 & 45.9 & 31.0 & 47.2 & 31.6 & 47.2 & 32.6 & 49.1 \\
\hline
\end{tabular}

4 The informal employment rate presents the share of people who are employed in the non-observed (shadow) sector of the economy as a percentage of the total number of employed people. The non-observed economy covers employees in non-registered companies and employees in registered companies but without a legal contract of employment and without being covered by social and pensions insurance. It also includes unpaid family workers. 


\section{Objectives of employment policy}

The objectives of the employment policy in the Republic of Serbia, as well as the priorities to be achieved in 2011, have been established taking into account both the guidelines and recommendations of the new Europe 2020 strategy for growth and development, and the actual state of affairs on the labour market in Serbia. The objectives of active labour market policy in 2011 are oriented towards:

1. increasing employment

2. investment in human capital

3. social inclusion. $^{5}$

\section{Priorities of employment policy}

Promoting employment and the social inclusion of disadvantaged and vulnerable categories of people into the world of work, as well as improving the educational level of the unemployed, is achieved through the execution of an active labour market policy and the accomplishment of its priorities. Many priority actions, oriented towards the achievement of the objectives, constitute a part of the process which has already begun and which is continuously unfolding. Activities started under the previous Action Plan for Employment continue in 2011 and subsequently.

The priorities of employment policy are:

1. striking a balance between demand and supply on the labour market

2. creating new jobs

3. improving education and training for the development of the skilled workforce

4. promoting the employment of vulnerable and disadvantaged categories

5. decentralisation and the promotion of the development of regional and local employment policies. $^{6}$

\section{Programmes and measures of active labour market policy}

Active labour market policy measures directed towards the improvement of employment and realised through the NES are the following:

1. mediation in the employment of job seekers

2. professional orientation and counselling as regards careers management

3. employment subsidies for employers

4. support for self-employment

5. additional education and training

6. incentives for people on unemployment benefit

7. public works

8. active labour market measures for people with disabilities

5 Ministry of Economy and Regional Development National Action Plan for Employment for 2011.

6 ibid. 
9. co-financing of active labour market programmes and measures from within the republic budget (at the request of a territorial autonomous or local self-government body). ${ }^{7}$

Active employment policy represents a system of plans, programmes and measures aimed at increasing employment and decreasing unemployment. The core instrument of active employment policy in the Republic of Serbia remains the National Action Plan for Employment.

\section{Mandatory unemployment insurance}

Mandatory unemployment insurance is part of the obligatory social insurance system for citizens under which unemployment rights are ensured on the basis of the principles of mandatory participation, reciprocity and solidarity. Mandatory insurance guarantees the following unemployment rights:

1. unemployment benefit

2. health insurance and pensions and disability insurance in accordance with the law 3. other rights in accordance with the law. ${ }^{8}$

The legal base for the calculation of unemployment benefit is the average salary or wage, or the salary reimbursement of the unemployed person, as appropriate, in the last six months prior to the month in which the employment contract or insurance was terminated. The amount of unemployment benefit equals $50 \%$ of this base. However, it may not be higher than $160 \%$ or lower than $80 \%$ of the minimum wage determined under labour regulations for the month in which the benefit is paid.

Unemployment benefit is paid to the unemployed person:

1. for three months, if the period of insurance cover spans one to five years

2. for six months, if it is from five to fifteen years

3. for nine months, if it is from fifteen to 25 years

4. for twelve months, if it covers a period longer than 25 years.

The beneficiary is entitled to health insurance and pensions and disability insurance during the exercise of the entitlement to unemployment benefit. Health and pensions and disability insurance contributions are contained in the amount of benefit and are paid at the expense of the beneficiary; the base in respect of which contributions are paid is equivalent to the amount of unemployment benefit.

\section{Informal employment in the Republic of Serbia}

The informal economy usually takes the form of undeclared, i.e. unregistered, work. This is often additional activity which brings supplementary income for the majority of stakeholders on the informal labour market.

In accordance with the national legislation in Serbia, the informal economy includes all workers employed in unregulated and unprotected positions; employees in unregistered companies; paid workers carrying out informal activities; etc.

7 Law on Employment and Unemployment Insurance Official Gazette of the Republic of Serbia $36 / 09$.

8 ibid. 
The Economic Sciences Institute in Serbia defines the informal economy as a wide range of economic activities or transactions conducted in a manner that does not respect legal norms or contribute to official GDP. The informal economy encompasses those economic activities which take place outside of regulated legal standards (the informal economy), or those that are in opposition to legal regulations (the illegal economy). The informal economy represents legal activities which, due to different reasons, are hidden from administrative and tax bodies. ${ }^{9}$

The growth of the informal economy over the last fifteen years has made this phenomenon the most important as regards the present labour market. In particular, the influence and power of trade unions are declining due to the decrease in the state sector and the growth of the informal economy, especially in large industrial centres. Moreover, weak state institutions in transition countries are creating favourable conditions for the growth of the informal economy.

Trade unions have repeatedly invited state bodies to adopt laws and ensure the application of the existing regulations in order to create an economic environment with as low a level of illegal work as possible and to impose specific measures on negligent employers, thus influencing the elimination of illegal work in all economic spheres in

9 Informal economy - 'The informal economy comprises all economic activities by workers and economic units that - in law or in practice - are not covered or are insufficiently covered by formal arrangements. These activities either operate outside the formal reach of the law or they are not covered in practice (i.e. although they operate within the formal reach of the law, the latter is not applied or not enforced)'. (Rosas and Corbanese, 2006)

Illegal economy - describes an economic activity taking place contrary to the law.

Unregistered activities - describes an economic activity that is not registered with an authorised economic body or court.

Hidden economy - all hidden or statistically unreported types of economic activity such as, for example, working at home.

The 'shadow economy' leads to two types of consequences: 'Direct consequences that refer to the direct material harm that is done to the economy through decreases in national product and in budgetary income, lower earnings and the reduction or total abolition of those labour, economic and social rights enjoyed by employed people in the formal sector, jeopardising in the process the standard and quality of life of those who work in the informal sector, etc; indirect consequences that include the creation of an unhealthy social and political climate, the generation of always new and riskier sources of social and industrial conflicts, the promotion of unhealthy competition, the violation of other rules of a fair and equal market game and the destruction of the tissue of the national economy and of moral and social standards.' (Marinković, 2006: 40) Flexibility - 'The ability to adjust to changing demands and/or needs.' (Rosas and Corbanese, 2006)

Flexibility is a term which includes two dimensions: it can refer to employers' desire for variable (flexible) labour inputs, in terms of numbers employed or hours worked, to match changing demand for products or services. It can also refer to changing the tasks and skills of employees to increase productivity. The first type is sometimes described as 'external', 'quantitative' or 'numerical' flexibility; the second as 'internal', 'qualitative'; or 'functional' flexibility; it can also refer to employees' desire for variable (flexible) contractual arrangements and working conditions to match changing private and domestic needs. Flexibility may concern different forms of contractual arrangement (including 'atypical work'), particularly as regards working time, to suit better work-life balance. 
Serbia. The unions emphasise that this issue needs to be resolved through a tripartite approach and social dialogue, and that it needs to be placed within the focus of the Social-Economic Council at the level of the Republic as well as at local levels. Labour market reform and the reform of the education system are also required, as well as the defining of a social policy which will contribute to the promotion of employment and an increase in the level of employment.

Particular factors in the growth of the informal economy are specific for transition countries:

- lack of trust in official institutions

- corrupt and ineffective administration

- disrespect for law and legislation

- high unemployment rate

- informality as a survival strategy for the poorest parts of the population

- high levels of expenditure and complex administration in the formal economy.

High tax rates are one of the basic reasons for the high volume of work in the informal economy. On top of that, complicated procedures and the large number of documents required for formal activities present additional incentives to shift work outside the formal economy. The authorities must improve the legislation in order to decrease the high number of licences required.

The following reasons for the high rate of the informal economy may also be identified as regards the case of Serbia:

- politics dominate the economy

- there is a lack of a real market system

- the tax system is inadequate and suffers from poor tax control

- potential risks are lower than potential profit

- economic policy towards the private sector is vague

- elements of cultural heritage and a lack of business ethics and morality play a role

- the war which lasted a number of years, accompanied by a significant inflow of refugees

- economic trends have been negative in the long-term

- there is an increasing number of unemployed people

- living standards are low

- transition processes are slow

- the existing economic system suffers from a lack of modernity and is simply ineffective

- there is a lack of systematic measures being taken by the state towards the suppression of the shadow economy.

The volume of the informal economy in countries of central and eastern Europe and south-east Europe was assessed to amount, on average, to $30 \%$ of 2001 GDP. The situation is similar in Serbia.

Participants in the informal economy in the Republic of Serbia belong to all age groups. Illegal work is directly related to the rate of unemployment while, out of the total number of the unemployed, the highest percentage is found among young people up to age of 30 so, currently in Serbia, it is young people who predominate among people working in the informal economy sector. 
The situation in terms of the employment of young people is extremely critical, especially if we take into consideration the following factors:

- $48 \%$ of young people between the ages of 15 and 30 do not have a job

- $43 \%$ of those young people who are employed do not have permanent employment

- approximately $40 \%$ of those who are employed are not registered, i.e. they are working illegally

- and, for the rest of young workers, employers are paying contributions which do not correspond to their level of education.

A lack of trust in state and state institutions is highly present among young people. They believe that their state pays more attention to the requirements of the international financial institutions and major foreign investors than it does to the improvement of the living standards of the population. A lack of trust in official institutions among young people creates realistic preconditions for the emergence and long-term existence of the informal economy. It is necessary to educate young people about their rights and the protection mechanisms which exist, as well as to provide them with the possibility to participate in the work of decision-making bodies at all levels of social activity.

Other than young people, the greatest proportion of participants in the informal economy is found among people older than 50 who have lost their jobs as a result of transition, privatisation and bankruptcy.

A large number of participants in the informal economy are those who have university education. This is not usually the case in countries which have a high volume of the informal economy; in other countries in the region, the informal economy is closely linked to a low level of education. Research shows that human resources are more adequately valued in the informal economy since the income of highly-educated workers is not only twice as high as those who have only a secondary education, it is six times higher than the income of highly-educated workers in the formal economy. This leads to the conclusion that level of education is not a condition for entering the informal labour market.

The gender structure of employees shows that more men are engaged in the informal economy in Serbia than women: the assessment is that employed women are, all other conditions being the same, $20 \%$ less inclined to engagement in the informal economy than men.

The informal economy is present in many fields of economic activity in Serbia: illegal import and export; undeclared foreign currency being brought into the country; flows of cash outside of operational payment channels; goods being sold on the shadow market; the defining of specific sales prices on the shadow market; tax evasion; disrespect for working hours; usage of materials and the equipment of state and public companies for private purposes; undeclared trade in handcrafts, construction and other services; incomplete declarations of income from private agricultural production; etc. The majority of the participants in the informal economy in Serbia fall into the category of unregistered or undeclared employment.

The informal economy is found particularly in construction, trade and services, i.e. small clothing shops, cafes, small handcraft shops and agriculture. These are mostly low-quality, temporary jobs performed under poor working conditions and without protection at the workplace. 
Over 100000 people are employed in the construction sector in Serbia. Estimates are that between $25 \%$ and $30 \%$ of people in the construction sector are working illegally - which is, therefore, approximately 30000 workers. It is the construction sector that has the highest rate of registered injuries resulting in death, on average eleven annually. This brings Serbia to the top of the list in terms of the number of deaths on construction sites in relation to the number of employees.

The scope of illegal work is massive in small private shops. Many employees work for only ten days and, at the time of the payment of their salary, are then dismissed from work with the owners employing new workers.

The informal economy is present in all regions of Serbia and is mostly evident in the production and trade of excise tax products. There are also specific features in specific regions, such as textiles and footwear production in Novi Pazar, as well as particular seasonal characteristics related, for example, to the purchase of agricultural products.

Analysts estimate that sales in the informal economy are being made at more than 100000 sales points all over Serbia, located in mixed and 'green' markets, 'home shops' or 'box boutiques' on the streets. Calculations based on an estimate that the average sales of goods at such improvised sales points amounts to $€ 50$ results in an amount of over $€ 5 \mathrm{~m}$ as daily turnover so, at a monthly level, this amounts to $€ 150 \mathrm{~m}$ and, at an annual level, to as much as $€ 1.8 \mathrm{bn}$. However, many sales points are more profitable than even in this example.

Very often, illegal work results from an agreement between employee and employer and, as a result, many employees do not want to report their employers. The big problem is that workers are willing to work to their own detriment, i.e. they are getting a higher salary instead of registered years of service and the right to retirement. Additionally, many of them seek protection only when some accident happens, when they get fired or when the time comes for retirement. In such cases, only the courts have jurisdiction and the first thing workers need to do when they get to court is to prove that they have been working. Workers trying to protect their jobs are withholding the true situation; hence, they are protecting their employers because labour inspectors cannot initiate an investigation without the statement of a worker in that workplace.

Regional differences are present in Serbia, and the labour market is generally poorer in rural than in urban areas, and in southern compared to northern areas, with a high concentration of significant resources in university centres. Most areas are faced with significant demographic and social problems, such as the high participation of elderly people and a high level of concealed unemployment, especially in areas where economic development is based on mechanical engineering and the textiles industry, or an immobile agricultural population.

\section{Inspection services}

In terms of inspection services, data show that efficiency has been increased here but that there are still numerous problems preventing inspectors from achieving the desired effects: poor functioning of courts; insufficient information technology capacities; poor equipment for inspectors in the field; a lack of linkage with other inspection services; non-existent co-operation with the tax authorities; an insufficient number of 
employees; low salaries for inspectors; inadequate and obsolete organisation; etc. In addition, the training needs for inspectors are obvious, as is the need to educate employees in the informal economy since many are not interested in paying social contributions. Bearing in mind the frequent changes in the legislation, there is also a need to educate employers and people engaged in the formal sector.

Implementation of the reform of the inspection services and the adoption of adequate legislation which should address the dilemmas of de-centralisation are one of the preconditions for a better functioning of the control mechanisms that do exist. Reform needs to provide for better vertical linkages of the inspection services and for a review of sanction policies, but also to open the issue of the control of the work of the inspectors and the criteria for their recruitment, as well as the need for their de-politicisation.

\section{The trade union role}

In relation to the engagement of trade unions in activities with employees in the informal economy, and the efforts being made to gain their confidence and to organise trade union education activities, the following needs to be done:

- act preventively, through contacts with and the education of pupils and students in their final years (lectures, debates, brochures, audios and videos and other modern methods) on a number of specific issues: trade unions and their programmes and manner of work in this area; international norms and standards; the labour market; employment opportunities; the 'advantages' and dangers of work in the 'shadow economy'; and the possible protections which can be provided by trade unions

- through social dialogue, seek to influence the content of curricula in vocational secondary schools and other secondary schools, as well as in universities - with the aim of students gaining knowledge about industrial relations (labour legislation; the regulation of relationships in the work process - i.e. collective bargaining and the conclusion of collective agreements; trade unions and the exercise of the rights and freedoms of association and organisation of trade unions;...) and to create the preconditions for a more developed system of industrial relations

- struggle for a full harmonisation of the education process with the realistic needs of a modern, market-oriented economy in order to overcome the situation in which we have a high unemployment rate and, at the same time, a high number of vacancies, mostly due to the inadequate qualifications structure among people looking for employment

- through the work of tripartite bodies, have a direct influence on legislative activities in terms of the adjustment of laws and other normative documents to the realistic situation and needs of each country (a combination of incentive measures and sanctions in order to ensure a greater interest in legal business operations)

- obtain the trust of employees in the informal economy (especially in the construction sector and trade, and among street retailers and employees in large shopping centres, etc.), with trade union activists getting among them to become familiar with their daily problems and to offer specific assistance through: 
- the establishment of free telephone helplines for legal and other advice to people engaged in the informal economy

- financial support and assistance if needed (e.g. in respect of the illness of a worker without an employment contract and, therefore, health insurance for members of his/her family)

- communication with the Labour Inspectorate in order not to expose informal sector employees and endanger their survival or the survival of their families

- provision of free legal aid or representation before a court in the event of a dispute

- establish contacts and co-operation with institutions (among youth and student associations) which might serve as a platform for the recruitment of a substantial part of employees in the informal economy, especially young people who are trying to find their first jobs

- strengthen co-operation and social partnership with employers in order to establish joint activities focused on the creation of the necessary assumptions and conditions for legal employment i.e. a reduction of illegal activities

- intensify co-operation with those non-governmental organisations which have experience of, and positive results from, working with those groups that are most likely to participate in the shadow economy

- educate trade union activists and enable them to recognise in practice, in the field, all forms of illegal work, especially those concealed within the framework of legal businesses (e.g. the payment of salaries in cash with the aim of avoiding the payment of taxes and contributions) and reacting to those occurrences in a proper and timely manner

- organise campaigns aimed at combating illegal work in those settings where this phenomenon is largely present, and within particular activities:

- organise round tables, debates and other topical events with the participation of the representatives of trade unions, the competent state bodies, organisations and institutions, and independent experts, professionals and analysts involved in this issue, as well as the representatives of workers in the informal economy

- conduct the education of, and capacity building among, trade union activists and workers in the informal economy around the need to take preventive actions in this domain and for specific engagement in resolving the problems which result from illegal work

- inform the public and participants in illegal activities about the situation in the area of illegal work, and especially on the practical possibilities for their protection by competent state bodies and trade unions (through different modern methods - flyers, leaflets, etc.)

- achieve a completely public nature of trade union activities, especially in relation to the measures and actions being undertaken, as well as the results which are realised in terms of the suppression of illegal work.

It is necessary to work continuously on the development and improvement of the social dialogue and the concept of equal social partnership - from local to national level - in order to be able to implement such measures and actions. 


\section{National Employment Strategy for the Period 2011-2020}

\section{Labour market policy challenges}

According to the National Employment Strategy for the Period 2011-2020, ${ }^{10}$ the main employment challenges are:
a) demographic challenge, labour migration and regional gaps
b) education challenge
c) institutional challenge
d) duality of the labour market.

\section{Demographic challenge}

The population of Serbia in 2010 was estimated at 7482000 individuals, i.e. $3 \%$ lower than was recorded in 1998. In 2010, a negative population growth rate, of $0.61 \%$, was also registered. Such a drop is the result of declining birth rates and continuing migration driven by economic transition and the lack of employment opportunities.

Changes in the concentration of the population at regional level indicate that polarisation into zones of concentration and zones of emigration and de-population is becoming more visible. Between 2002 and 2008, over one-half of Serbian municipalities recorded a demographic drop, with nineteen municipalities experiencing a decline exceeding $10 \%$. This depopulation trend, typical of undeveloped, border municipalities, poses the issue of demographic abandonment in those areas.

Serbia is faced with all kinds of migration: external and internal; forced and voluntary; legal and illegal; of highly-skilled and unskilled workers; and the challenges of both immigration and emigration. Over the past decades, the migration policy of the Republic of Serbia has been driven by the need to provide for the thousands of involuntary migrants driven from their homes by ethnic violence and military activities.

The pronounced development gaps in Serbia have a multi-dimensional character, i.e. they are determined by geographic, economic, social, demographic and cultural factors. The key regional development challenges are reflected in marked depopulation, high unemployment, low economic activity and, in particular, in the lack of competitiveness of the industrial systems that should be the drivers of regional development, as well as of the infrastructure necessary to drive economic development.

\section{Education challenge}

The education structure of the Serbian population is another challenge. The problems of the education system have not been resolved: dropouts at all levels of education are still high and a majority of education indicators are among the worst in Europe. About $10 \%$ of the population has not completed primary school (either on the basis that people were never enrolled or have dropped out). Approximately $90-95 \%$ of those who complete primary school enrol in secondary education (about $80 \%$ of the cohort). 
Approximately $15 \%$ of these, however, do not complete secondary education (about $35 \%$ of the cohort): only $13 \%$ complete post-secondary education.

The situation is somewhat better when only the active population is taken into account, but the rate is still far below the EU average (19\% of the active population has a university degree compared to the EU average of $30 \%$ ). The reduction in the number of people leaving school early, and an increase in the share of university-educated individuals in the total population, which are EU priorities, remain a challenge for Serbia.

\section{Institutional challenge}

The institutional framework for the design and implementation of employment policy in Serbia has made substantial progress. Employment policy is now part of wider economic policy and is directed towards both job creation and the promotion of employment.

\section{Duality of the labour market}

The Serbian labour market has many dual dimensions:

- formal and informal markets

- public vs. private sector

- permanent and fixed-term employment

- younger and older labour force

- men and women

- educated and low-skilled labour force.

\section{Objectives}

Overarching objective - increasing employment

Within the framework of Europe 2020 and the strategic commitment of the Republic of Serbia to achieve economic progress, with respect to the characteristics of the labour market, the aim of employment policy is to achieve, by the end of 2020, an efficient, stable and sustainable employment growth trend and to align employment policy and labour market institutions fully with the EU acquis. The reduction of differences in labour market indicators between Serbia and the EU is one of the priorities for this Strategy.

Employment growth and, as a strategic aim, sustainable employment growth, in particular in the private sector, depends on an increase in both the number and the quality of jobs.

The post-crisis economic growth model requires an improvement in the investment and the business environment, as well as indirect and direct state intervention to create the conditions which are conducive to the creation of jobs. In particular, support for foreign direct investment and export-oriented programmes are interventions that should be supported as a means of creating new jobs.

Priority activities that should contribute to employment growth are support for job creation in small- and medium-sized enterprises (SMEs) and incentives for entrepreneurship. SMEs are the most important factor in the development of the country 
and the sustainability of growth. Private companies have a smaller share of economic production but a large share of foreign trade. High operation costs, on the one hand, and the contraction of demand as a consequence of the crisis on the other have both contributed to a reduction of the number of companies as well as to lay-offs. This is why more measures and incentives are required to prevent the continuation of this process.

The actions envisaged in Serbia's new growth model are also expected to advance social entrepreneurship, co-operatives and other forms of enterprises. Support for the development of companies and organisations active in the 'third sector' and the 'nonprofit' field is necessary given the role that these play in carrying out economic activities and providing services to improve the quality of life of the most vulnerable groups.

Specific objectives

To achieve these strategic aims, and in line with the challenges identified, a number of specific objectives have been defined to contribute to employment growth in the Republic of Serbia, through the implementation of various programmes, measures and activities.

These specific objectives are:

a) stimulating employment in less-developed regions and developing regional and local employment policies

b) enhancing the quality of human capital

c) development of institutional capacity and the expansion of active labour market policies

d) reducing the duality of the labour market.

\section{Conclusion}

The implementation of the National Employment Strategy for the Period 2011-2020 requires a combination of measures and activities, accompanied by the adoption of new laws and the evaluation of existing provisions, policies and programmes to make faster and more efficient progress in tackling the issue of unemployment.

The Employment Strategy is being operationalised through the National Action Plan for Employment, which is the basic tool for implementing active employment policy measures on an annual basis. The Plan translates employment policy goals and priorities into specific programmes and measures to be implemented.

The implementation of the Plan is monitored through performance indicators that measure the outcomes of active labour market programmes and assign responsibilities for implementation and for financial resources.

\section{References}

Kosanović, Rajko (2010) Sindikalni leksikon (Trade Union Lexicon) Friedrich-EbertStiftung and 'Obeležja', Beograd.

Marinković, Darko (2006) 'Shadow labour markets as an obstacle to strengthening the competitiveness of companies' South-East Europe Review for Labour and Social Affairs 9(4): 31-42. 
National Employment Service of the Republic of Serbia (December 2010) Monthly Statistical Bulletin - Unemployment and Employment in the Republic of Serbia No. 100 .

Paunović, Sanja (2008) Neformalna ekonomija u Republici Srbiji: Studija slučaja: Regionalni primer: Pčinjski okrug - Vranje Savez samostalnih sindikata Srbije, Swiss Labour Assistance, Radnička štampa: Beograd.

Paunović, Sanja and Rajko Kosanović (2010) Ekonomija u senci (Shadow Economy) Savez samostalnih sindikata Srbije, Pan-European Trade Union Council, Radnička štampa: Beograd.

Rosas, Gianna and Valli Corbanese (2006) Glossary of the key terms on learning and training for work International Training Centre, ILO.

Statistical Office of the Republic of Serbia (April 2011) Labour Force Survey.

Statistical Office of the Republic of Serbia (2011) Monthly Statistical Bulletin 2/2011: Beograd.

National Action Plan for Employment for 2011 Official Gazette of the Republic of Serbia 55/2010 and 4/2011.

National Employment Strategy for the Period 2011-2020 Official Gazette of the Republic of Serbia 37/11.

Law on Employment and Unemployment Insurance Official Gazette of the Republic of Serbia 36/09.

Law on the Professional Rehabilitation of Persons with Disabilities Official Gazette of the Republic of Serbia 36/09. 